\title{
Estudo Computacional para Otimizar a Identificação de Minerais
}

Alfredo A. A. E. de Queiroz ${ }^{a}$, Marcelo B. Andrade ${ }^{a}$.

${ }^{a}$ Instituto de Física de São Carlos, Universidade de São Paulo, São Carlos, Brasil.

Os minerais têm diversas aplicações, como na indústria de aço que utiliza os minérios de cobre e ferro. Outra aplicação seria por meio de seu arranjo atômico, servindo como base para a elaboração de novos compostos sintéticos [1] (como a menezesita e seu sintético $\left.\mathrm{Mg}_{7}\left[\mathrm{MgW}_{12} \mathrm{O}_{42}\right](\mathrm{OH})_{4} \cdot 8 \mathrm{H}_{2} \mathrm{O}\right)$. Atualmente, o Brasil possui apenas 70 minerais-tipo completamente caracterizados, índice baixo comparado com a variedade de ambientes geológicos em seu território.

Com o intuito de agilizar o processo de identificação das amostras de minerais, este trabalho busca utilizar os espectros característicos Raman e os parâmetros cristalográficos como referência para ferramentas computacionais.

Para realizar a identificação dos minerais por meios dos espectros Raman e raios-X, propõe usar rede neural artificial (RNA). Nesse caso, os componentes principais deverão ser capazes de facilitar o processo de aprendizagem de uma RNA e reduzir os custos operacionais pelo descarte de variáveis adicionais.

Os avanços na área de computação permitem criar através de linguagens de programação, redes neurais artificiais (RNAs) capazes de reconhecer informações e produzir respostas seguindo a teoria de aprendizagem cognitiva, se adaptando a mudanças de controle, classificação e processamento ao longo do tempo [2].

[1] Atencio, D., Brazilian Journal of Geology, 45, 143-158 (2015).

[2] DUCH W., DIERCKSEN G.H.F., Neural networks as tools to solve problems in physics and chemistry, Computer Physics Communications, Vol. 82, pp. 91-103 (1994).

Acknowlegments: os autores agradecem ao CNPq (131650/2017-3) e a FAPESP (13/03487-8) pelo financiamento parcial deste trabalho. 